\title{
Integrative and Collaborative Education Models in Primary School Teacher Education Department
}

\author{
Wahyu Sukartiningsih \\ PGSD Department, Surabaya State University \\ Surabaya, Indonesia \\ Corresponding e-mail: wahyusukartiningsih@unesa.ac.id
}

\begin{abstract}
In the application of Integrated Thematic learning in the 2013 Curriculum, for the early grades (I to III class grade), Indonesian subjects are filled with science and social studies subjects. Therefore, it is necessary to prepare materials that accommodate each of the characteristics of Indonesian, Natural and Social Science Subjects in primary school. Packaging of the materials will be used as teaching materials of Indonesian Language Education in the Early Primary School. The objective at the early stages of this research is to formulate teaching materials of Indonesian Language Education Court in Early Class of Integrated Natural Science. and Social Science Subjects based on Scientific approach to optimize student competence of Primary School Teacher Education Department. The design of this research is research development (R \& D). Data collection techniques in formulating teaching materials are observation, questionnaires, and interviews about the need of teaching materials products of the Constitutional Court of Education in the Primary Class of the relevant and qualified Primary Schools. Data on the need of teaching materials products are analyzed descriptively statistically, in the form of average and percentage. The result of the research showed (1) the need of teaching materials and (2) the draft of the teaching materials of the Indonesian Language Education Court Integrated Natural and Social Science in the Early Class of Primary School.
\end{abstract}

Keywords: : teaching materials, Indonesian Education, integrated learning, collaborative education

\section{INTRODUCTION}

The development of multiple intelligences (multiple intellegence) is a comprehensive development that must be grown from an early age. Efforts to cultivate multiple intelligences is a necessity for children to survive in the learning process and life in the future. According to Gardner (1983), a minimum of nine human intelligence, namely (1) Linguistic intelligence (the ability to use the vocabulary effectively, both oral and written); (2) logicalmathematical intelligence (deductive and inductive / reasoned thinking abilities, numeracy, and abstract patterns of thought); (3) spatial intelligence (the ability to use their senses of sight and the ability to visualize objects, and create images-mental / painting); (4) bodily-kinesthetic intelligence (the ability to express ideas and feelings through gestures in the form of dance or craft); (5) musical intelligence (sensitivity to pitch / melody tone color / sound, both as lovers, composers, or critic); (6) interpersonal intelligence (ability to communicate / socialize with others); (7) intrapersonal intelligence (self-understanding, strength, and self-weakness); (8) naturalist intelligence (recognize and classify florafauna); and (9) an existential intelligence (the ability to put yourself in the farthest reach of the cosmos-infinite size, related to the existential aspect of man, for example the meaning of life, death, love, and so on).

Multiple intelligence needs to be developed comprehensively and integrated in a child at the right age. Unequal intelligence can lead to inequality also in one's behavior. For example, the facts in society today show that cognitive intelligence alone is not enough to be a complete human being. Many facts show the existence of human beings who are high in cognitive intelligence, but very low in their interpersonal and existential intelligence. The inequality of the intelligence affects the inhibition of a person to become a useful and useful individual for himself and the people around him.

The growth of multiple intelligences needs to be facilitated early on through teaching materials and learning. Therefore, the development of teaching materials that can facilitate multiple intelligences at an early age, especially in primary school, is very important. This research can be the answer to this challenge through the development of integrated learning materials Threaded Model 
to cultivate a compound intelligence of elementary school students.

The National Education System Act (UU) No. 20/2003 and more explicitly Government Regulation number $19 / 2005$ on National Education Standards (SNP) juncto Government Regulation number 32 of 2013 on the amendment of Government Regulation No. 19 Year 2005 on National Standards of Education, states that Indonesian students through the education process should be able to (a) have a basis of intelligence, knowledge, personality, noble ahklak, and skills for independent living and follow further education; (B) have life skills including personal skills, social skills, academic skills, and vocational skills. The 2013 curriculum seeks to address these future challenges by establishing an integrated approach, in which all subjects involved in one lesson are linked to a particular theme. (Permendikbud, 2013: $35)$.

Previous related research ever conducted by Sugiarto, et al. (2009) is developing thematic materials for class I semesters 1 and 2 as an effort to instill students' thinking skills. Research conducted by Yuliati, et al (2007) managed to develop packages and models of learning and writing based on multiple intelligences for students with special needs. Research conducted Sukartiningsih and Rukmi (2010) developed an interactive CD as a medium to optimize the compound intelligence of elementary students. From the various studies it seems that the development of multiple intelligences can be done through the development of strategies and learning media in the elementary school, the research that will do this has advantages, namely (1) research to develop a model of learning that can be used practically by teachers to cultivate multiple students' intelligence; (2) integrated learning Threaded models developed in this study are not simply impose a thematic learning model as stated in Curriculum 2013, but also facilitate the growth of multiple intelligences elementary students by facilitating integrative approach and contextual; (3) integrated learning Threaded models is one of the integrated learning model that combines several areas of study to achieve a certain competence, so that teachers can focus on the planning and implementation of an integrated learning for the achievement of competence; and (4) the study was not just making a model by combining integrative approach and contextual approach, but also produces instructional teaching materials that can be used by teachers as a model of multiple intelligences foster student learning.

Based on the need to cultivate multiple students' intelligence and support teachers in carrying out their duties to develop multiple children's intelligence, it is urgent to undertake needs analysis studies entitled Analysis of Integrated Learning Needs of Threaded Models to Grow Multiple Intelligences of Primary School Students ".

\section{A. Approach and Type of Research}

This study uses a Research \& Development ( R \& D) approach using 10 Borg \& Gall (1983) stages modified in context and implemented in 10 stages: (1) survey: needs analysis \& constraints; (2) review of literature and research products 6) major product revisions, (7) primary field tests, (8) revisions of applied products, (9) final product revisions (10) dissemination to the wider arena. However, from 10 stages, this study focuses only on stage 1, namely (1) survey: needs analysis \& constraints.

\section{B. Research Procedures}

Preliminary research activities include needs analysis and constraint analysis. The purpose of the activity in stage 1 is the assessment and identification of the problems and the reality that occurs in the growth of the student's primary intelligence. Activities undertaken include: (1) Survey and observation of needs analysis, analysis of classroom observation constraints and student competencies in selecting, defining, planning, implementing and assessing integrated learning learning materials Threaded model by conducting interviews with lecturers and undergraduate students and (2) Review of theories related to the concept of Integrated Learning Model, Contextual Approach, and Multiple Intelligence on Elementary School Students.

\section{Time and Place of Research}

The study was conducted within 4 months. The research sites consist of two locations, namely (1) in Unesa Campus for device development and validation, and (2) several primary schools for testing. For the collection of data on the implementation of the device implemented in primary school.

\section{Data Collection Techniques and Research Instruments}

Data collection is done for one semester. The techniques used include: (1) Observation, 
(2) Spreading questionnaires, (3) Interviews, and (4) literature studies. The instruments of this study include (1) observation sheets, (2) questionnaires, (3) Interview Sheets, and (4) analysis cards.

\section{E. Data Analysis Technique}

Data analysis in this research is done by using descriptive statistic analysis technique to result data (1) Observation, (2) Spreading of questionnaire, (3) Interview. As for analyzing the literature study data is done through content analysis techniques.

\section{RESEARCH RESULT}

F. Need Analysis Threaded Integrated Learning Model for Growing Multiple Intelligence of Primary School Students from the Questionnaire

From the questionnaire given to 3 teachers SD obtained the following data.

Table 4.1 Data Contents Teacher Angkets

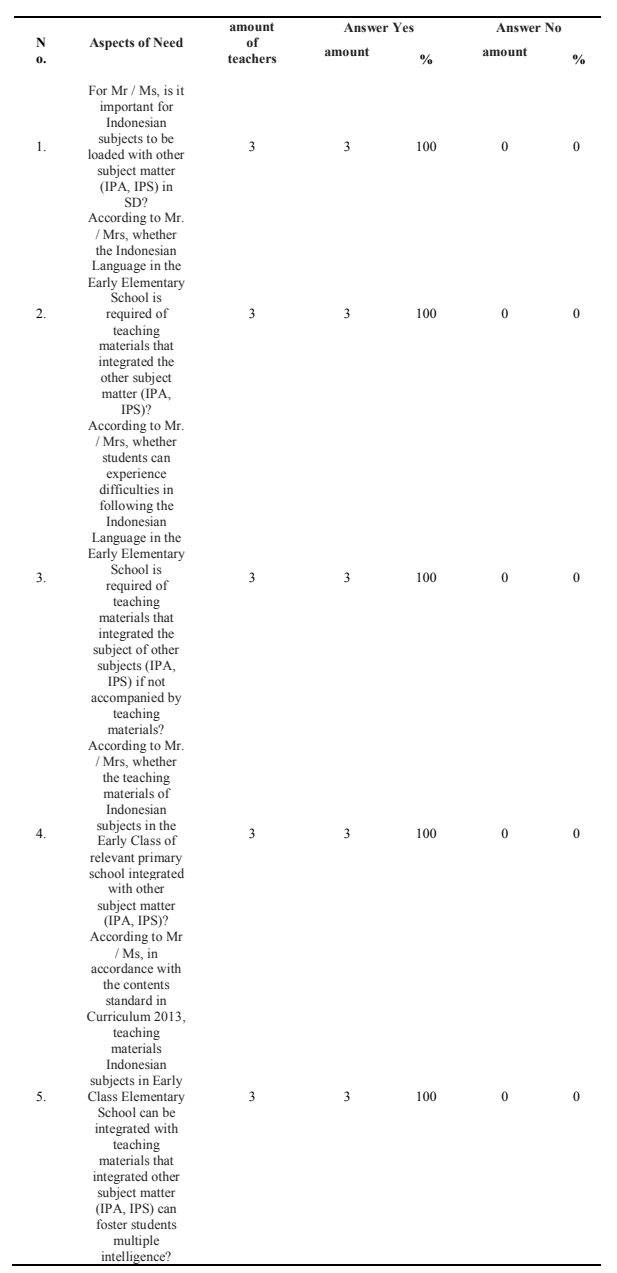

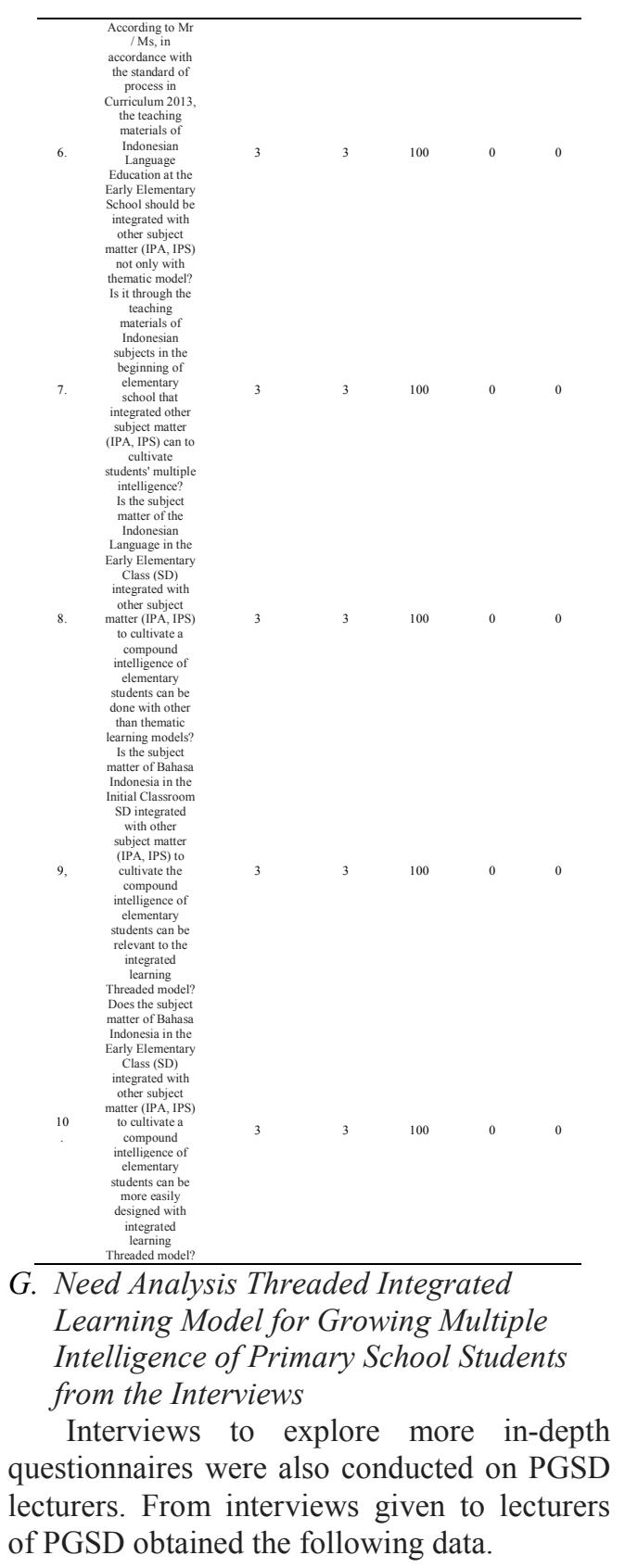

Table 4.2 Interview Data with Teachers

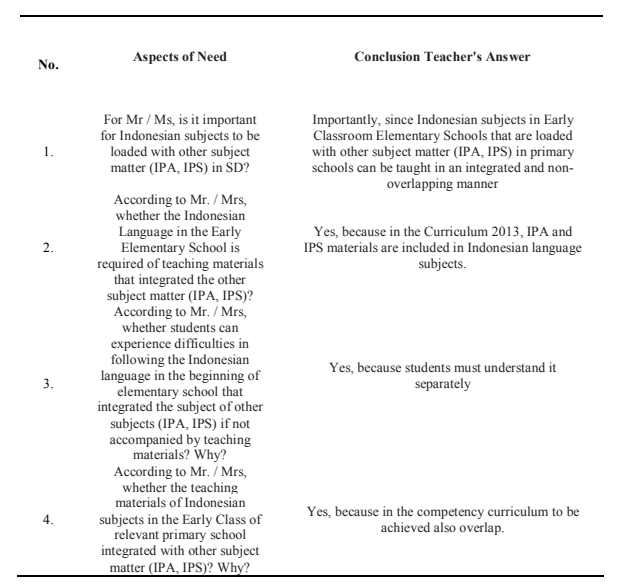




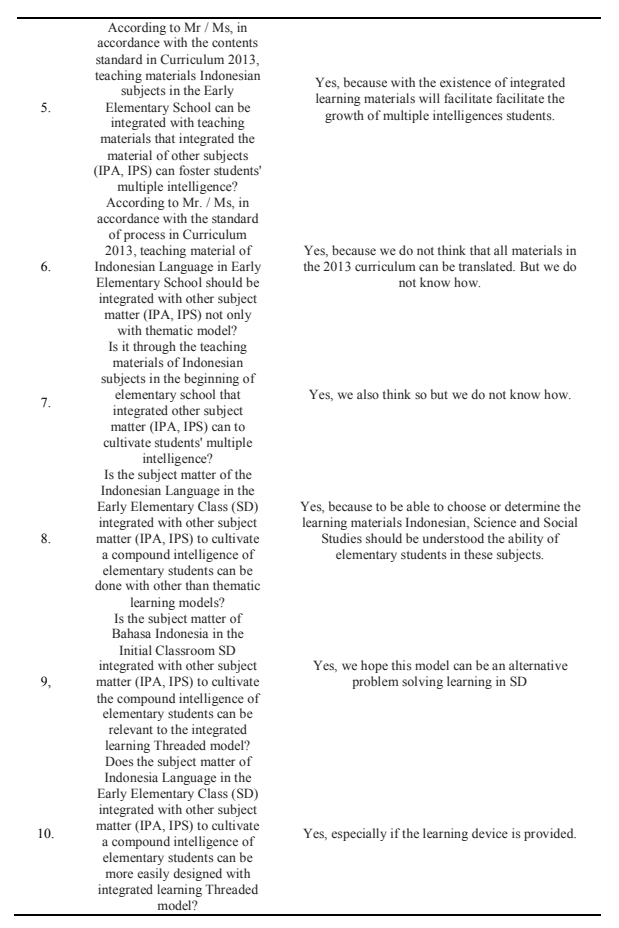

From the data of the questionnaire and interview to the elementary school teacher showed that the teaching materials of Indonesian Language Education in the Initial Class of IPA-IPS Integrated Elementary School is needed to be developed.

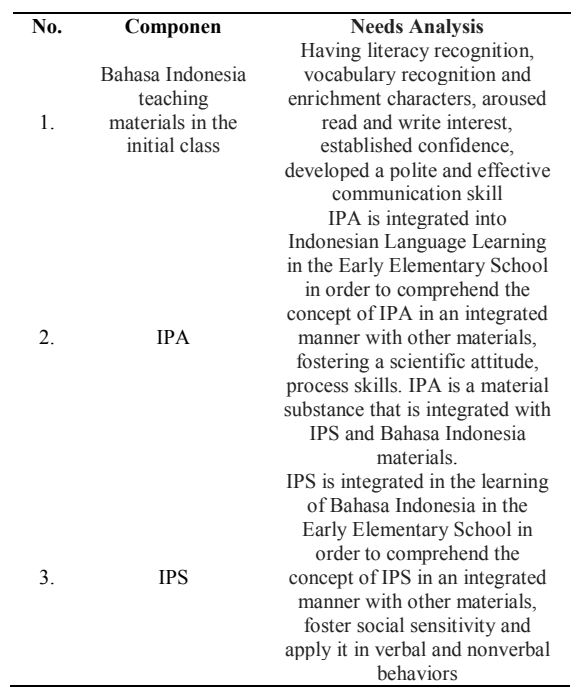

\section{REFERENCES}

[1] Borg, Walter R. and Gall, Meredith Damien. 1983. Applying Educational Research: A Praktical Guide for Teachers. New York: Longman.
[2] Damayanti, Maryam Isnaini dan Wahyu Sukartiningsih. 2004. Pembelajaran Konstruktivisme dalam Meningkatkan Kemampuan Membaca dan Menulis Permulaan Di Kelas 1 SDN Arjosari I. Laporan Penelitian Tidak Diterbitkan. Surabaya: Lembaga Penelitian UNESA.

[3] Fogarty, Robin. 1991. How to Integrated The Curricula. Palatine, Illonis: IRI/Skylight

[4] Galbreath J.1999. " Preparing the 21th Century Worker: The Link Between Computer Based Technology and Future Skills Sets" Educational Technology. Desember 1999 pp. 14-22

[5] Hill, T. A. 2005. Character First. Kimray Inc. $\quad$ http://www.charactercities.org/ downloads/publications/Whatischaracter. pdf. Diakses tanggal 11 Juni 20101

[6] Johnson. E.B. 2000. Contextual Teaching and Learning. California: Corwin Press, Inc.

[7] Mitrafm. Kecerdasan Spiritual Menentukan Jati Diri. Diakses pada Tanggal 05 Juni 2010 dari http://mitrafm.com/blog/2008/12/15/kecer dasan-spiritual-menentukan- jati-diri.

[8] Rukmi, Asri Susetyo dan Wahyu Sukartiningsih. 2002. Pengembangan Media Kartu Kata Bergambar untuk Pembelajaran Membaca dan Menulis Permulaan di Kelas 1 SD. Laporan Penelitian Tidak Diterbitkan. Surabaya: Lembaga Penelitian UNESA.

[9] Sugiarto, Bambang, dkk. 2009. Pengembangan Bahan Ajar Tematik Kelas I SD untuk Pemberdayaan Kemampuan Berpikir, Kecakapan Hidp, Psikomotor, dan Hasil Belajar Kognitif Siswa. Laporan Penelitian. Tidak Diterbitkan. Surabaya: Lemlit UNESA

[10] Sukartiningsih, Wahyu dan Yermiandhoko, Yoyok. 2008. Pengembangan Media CD Interaktif untuk Pembelajaran Membaca Permulaan di kelas 1 Sekolah Dasar. Laporan Penelitian. Tidak Diterbitkan. Surabaya: Lemlit UNESA

[11] Sukartiningsih, Wahyu, dkk. 2005. Penggunaan Strategi Problem Based Learning untuk Meningkatkan Kemampuan Membaca Kritis Mahasiswa Program D2 PGSD-UNESA. Laporan Penelitian. Tidak Diterbitkan. Surabaya: Lemlit UNESA. 